\title{
ANALISIS WACANA KRITIS IDENTITAS PELAKU DAN KORBAN PADA KORAN SANKEI DAN ANTARANEWS
}

\author{
A.A.N. Janardana ${ }^{1}$, G. S. Hermawan ${ }^{2}$, K.E.K Adnyani ${ }^{3}$ \\ ${ }^{123}$ Jurusan Pendidikan Bahasa Jepang, Universitas Pendidikan Ganesha, Singaraja \\ e-mail: agung.Indota@gmail.com, satya.hermawan@undiksha.ac.id, krishna.adnyani@undiksha.ac.id
}

\begin{abstract}
Abstrak
Penelitian ini bertujuan untuk menganalisis perbedaan pengungkapan identitas pada pelaku maupun korban yang ditampilkan pada koran Jepang dan koran Indonesia. Objek pada penelitian ini adalah Koran Sankei dan koran Antaranews yang dipublikasi pada bulan Oktober 2019. Dikumpulkan dengan metode dokumentasi, kemudian dianalisis dengan menggunakan metode deskriptif kualitatif. Hasil penelitian ini menunjukkan bahwa dalam mengungkapkan identitas pelaku dan korban, koran Sankei melakukan permarginalan terhadap aktor pelaku, dengan tidak digunakannya kata sandang dalam menyebutkan identitas nama, pemakaian diksi untuk menyebut jenis kelamin yang memiliki tingkat kesopanan lebih rendah dan sebagian besar berita yang menampilkan identitas aktor pelaku secara spesifik. Sedangkan dalam mengungkapkan identitas pelaku dan korban pada koran Antaranews, dilakukan permarginalan terhadap aktor korban dengan menampilkan identitas korban secara spesifik.
\end{abstract}

Kata kunci: analisis wacana kritis, pelaku dan korban, koran Sankei dan Antaranews

\section{要旨}

本研究の目的は、日本の産経新聞とインドネシアのアンタラニュース新聞の比較に おける犯人と被害者の表現を研究して明らかにすることである。本研究の対象は 10 月2019年に発射産経新聞とアンタラ新聞でデータを収集してある。研究では、記述 的定性的によって分析してある。データの収集はいずれも新聞のホームページに検 索して、見つかったデータを書類選考に募集することである。研究の結果は産経新 聞に投稿した記事は犯人に罰を与える目標で犯人の実名報道が行われることが多い である。被害者の指名と違って犯人の指名に「さん・くん」がついてある。犯人の 実名報道が行われなければ一般的に丁寧単語あらずに報道をすることになってある

反対にアンタラニュース新聞は被害者のプライバシー権を守りがっていないで被 害者の実名報道が行われることが多いである。

キーワード：批判的談話分析、犯人と被害者、産経新聞とアンタラニュース新聞

\section{Pendahuluan}

Era globalisasi menjadi era di mana manusia diberikan kemudahan untuk berkomunikasi dan mengakses segala informasi yang ada di dunia. Pada era globalisasi ini perkembangan teknologi informasi komunikasi menjadi lebih cepat dibandingkan era sebelumnya. Inilah mengapa abad ke-21 dikatakan sebagai abad komunikasi massa (Rakhmat, 2001: 174). Abad komunikasi massa tersebut ditandai dengan munculnya media massa sebagai alat komunikasi massa. Pesatnya perkembangan teknologi informasi komunikasi ini mencangkup adanya inovasi baru dalam media massa yaitu berupa media online. Komunikasi masa dalam media online lebih efisien, menghemat waktu, serta menyajikan informasi dengan tampilan yang praktis dan mudah diakses dimanapun. Informasi yang disajikan pun berasal dari berbagai sumber pemberitaan, bahkan hingga pemberitaan mancanegara pun dapat diakses dengan mudah melalui internet. Informasi yang dimuat dalam pemberitaan ini ada berbagai macam seperti politik, kuliner, olahraga, dokumenter dan juga kriminalitas.

Di dalam suatu pemberitaan tentunya diperlukan sebuah topik berita, tema berita, judul berita, isi berita, dan identitas seseorang yang menjadi subjek peristiwa. Akan tetapi pada pemberitaan dengan topik kriminalitas, diberlakukan anonimitas pada identitas apabila dibutuhkan. Di Indonesia sendiri pada pemberitaan media cetak dan online penyebutan anonimitas di dalam pelaku maupun korban itu menggunakan nama inisial jika diperlukan. 
Penggunaan anonimitas tidak hanya dapat ditemukan pada pemberitaan di Indonesia, namun berdasarkan pengamatan terhadap pemberitaan di Jepang, dapat ditemukan juga penggunaan anonimitas, tetapi dengan cara yang berbeda.

Dari lima kutipan berita pada pemberitaan online di Jepang, dapat ditemukan penggunaan anonimitas pada pelaku dan korban pada pemberitaan dengan topik kriminalitas, tetapi dengan cara dan bentuk yang berbeda, seperti misalnya mengganti identitas nama dengan jenis kelamin. Secara sekilas jika dibandingkan, terdapat perbedaan antara koran Indonesia dengan koran Jepang dalam mengungkap identitas diri pelaku mapun korban. Perlu dilakukan kajian lebih dalam mengenai perbedaan pengungkapan identitas pada pelaku maupun korban pada koran Jepang dan Indonesia. Hal ini penting dilakukan untuk dapat mengetahui keanekaragaman pengungkapan identitas pelaku maupun korban di dalam pemberitaan kriminalitas disetiap negara khususnya Indonesia dan Jepang. Keanekaragaman ini perlu diketahui untuk dapat menambah wawasan dalam bidang ilmu komunikasi lintas budaya yang berupa tulisan dalam bentuk wacana koran. Dalam melakukan kajian tersebut diperlukan suatu pendekatan yang dapat digunakan dalam melakukan analisis terhadap suatu wacana. Pendekatan yang dipergunakan adalah analisis wacana kritis, terlihat dari penelitian-penelitian relevan sebelumnya yang juga melakukan analisis terhadap suatu wacana.

Analisis wacana kritis memiliki tujuan untuk menguraikan dan memberi penjelasan dari sebuah teks wacana yang akan dikaji untuk memperoleh apa yang diinginkan. Teori analisis wacana kritis yang dipergunakan adalah Theo Van Leeuwen (dalam Darma, 2014), yang memperkenalkan pendekatan analisis wacana untuk mendeteksi dan meneliti bagaimana seseorang atau suatu kelompok ditampilkan dalam suatu pemberitaan.

Di Indonesia terdapat 7 penerbit berita nasional online terpopuler yang dilansir dari situs alexa traffic rank. Dari 7 berita nasional online, yang diangkat dalam penelitian ini adalah koran Antaranews. Hal ini dikarenakan Antaranews merupakan satu-satunya kantor berita yang merupakan BUMN yang diberikan tugas oleh Pemerintah Indonesia untuk melakukan peliputan dan penyebarluasan informasi yang cepat, akurat, dan penting, ke seluruh wilayah Indonesia dan dunia internasional. Tentunya tingkat akurasi dalam pemberitaan ini menjadi dasar alasan diangkat ke dalam penelitian.

Di Jepang terdapat 5 penerbit berita nasional online terpopuler yang dilansir oleh Yabai.com yang merupakan situs artikel online yang menampilkan penemuan-penemuan segar dan informasi berharga yang tidak banyak diketahui khalayak mengenai Jepang. Dari 5 berita online, yang diangkat dalam penelitian ini adalah koran Sankei. Hal ini dikarenakan hanya koran Sankei yang menyediakan akses penuh untuk pemberitaan yang secara khusus memuat tentang segala tindak kriminalitas sehingga data penelitian dapat diperoleh secara akurat dan aktual.

Berdasarkan latar belakang masalah tersebut adapun rumusan masalah yang dapat dirumuskan adalah bagaimanakah perbedaan pengungkapan identitas pada pelaku maupun korban yang ditampilkan pada koran Sankei Jepang dan koran Antaranews Indonesia. Tujuan dilakukan penelitian ini adalah untuk menganalisis perbedaan pengungkapan identitas pada pelaku maupun korban yang ditampilkan pada koran Sankei Jepang dan koran Antaranews Indonesia.

\section{Metode}

Penelitian ini menggunakan metode desktriptif kualitatif yakni menganalisis suatu wacana atau masalah dengan mengumpulkan beberapa data dan mendeskripsikannya melalui katakata. Wacana yang akan dianalisis atau subjek penelitian yaitu ada pada koran online Sankei (Jepang) dan Antaranews (Indonesia) yang dipublikasi pada bulan oktober 2019. Dalam pengumpulan data digunakan metode dokumentasi Pada koran online Sankei dan Antaranews akan dibandingan bagaimana kedua koran online tersebut menampilkan identitas pelaku maupun korban. Teori Theo Van Leeuwen pada dimensi proses pemasukan (Inclusion) digunakan untuk menganalisis wacana berita kriminal kedua koran online tersebut.

Analisis Theo Van Leeuwen (dalam Eriyanto, 2001) secara umum menampilkan bagaimana pihak-pihak dan aktor (bisa individu ataupun kelompok) ditampilkan dalam pemberitaan. Pada dimensi proses pemasukan (Inclusion) berhubungan dengan bagaimana 
masing-masing pihak atau kelompok ditampilkan didalam suatu pemberitaan. Dalam proses Inclusion menggunakan strategi wacana dengan memakai kata, kalimat, informasi atau susunan bentuk kalimat tertentu, masing-masing kelompok direpresentasikan dalam teks. Di dalam proses Inclusion terdapat beberapa macam strategi wacana yang diigunakan ketika seseorang atau kelompok ditampilkan dalam teks.

\section{Diferensiasi-indeferensiasi}

Yang dimaksud dengan diferensiasi-indeferensiasi adalah bagaimana suatu kelompok atau peristiwa direpresentasikan dalam teks. Penghadiran kelompok atau peristiwa lain tersebut secara tidak langsung menunjukkan bahwa kelompok itu tidak bagus dibandingkan dengan kelompok lain. Hal ini dapat dilihat dalam contoh berikut: indiferensiasi: Buruh pabrik Maspion sampai kemarin masih melanjutkan mogok. diferensiasi: Buruh pabrik Maspion sampai kemarin masih melanjutkan mogok. Sementara tawaran direksi yang menawarkan perundingan tidak ditanggapi oleh para buruh.

\section{Objektivasi-abstraksi}

Yang dimaksud dengan objektivasi-abstraksi adalah berkaitan dengan informasi mengenai suatu peristiwa atau aktor yang ditampilkan dengan memberi petunjuk yang konkret atau abstraksi. Seperti pada contoh berikut: Contoh (objektivasi): Pesawat maskapai penerbangan Lion Air telah dua kali mengalami kecelakaan. Contoh (abstraksi): Pesawat maskapai penerbangan Lion Air telah berulang kali mengalami kecelakaan.

\section{Nominasi-kategorisasi}

Yang dimaksud dengan nominasi-kategorisasi adalah berkaitan dengan informasi mengenai aktor atau peristiwa yang ditampilkan apa adanya atau dengan menyebut kategori tertentu. Kategori ini bisa berupa agama, ras, status sosial, bentuk fisik, dan sebagainya. Misalnya dalam contoh kalimat berikut: nominasi: Seorang wanita ditemukan tewas. Diduga sebelumnya diperkosa. kategorisasi: Seorang wanita karyawan ditemukan tewas. Diduga sebelumnya diperkosa.

\section{Nominasi-identifikasi}

Strategi wacana ini hampir sama dengan strategi nominasi-kategorisasi. Bedanya dalam identifikasi, proses pendefinisian dilakukan dengan memberi anak kalimat sebagai penjelas. Seperti pada contoh berikut: Nominasi: Seorang wanita ditemukan tewas. Diduga sebelumnya diperkosa. Identifikasi: Seorang wanita yang sering keluar malam ditemukan tewas. Diduga sebelumnya diperkosa.

\section{Determinasi-indeterminasi}

Indeterminasi adalah aktor atau peristiwa disebutkan secara jelas, sedangkan determinasi adalah actor yang disebutkan secara tidak jelas (anonim). Seperti pada contoh berikut: Contoh (indeterminasi): Arifinto mengundurkan diri dari jabatannya sebagai anggota DPR RI. Contoh (Determinasi): Kader PKS mengundurkan diri dari jabatannya sebagai anggota DPR RI.

\section{Asimilasi-individualisasi}

Ketika dalam proses hadirnya wacana atau pemberitaan bukanlah aktor sosial yang spesifik yang disebut, melainkan komunitas atau kelompok sosial di mana seseorang tersebut berada, di situlah terjadi strategi wacana yang disebut asimilasi. Misalnya bisa dilihat dari kalimat berikut: Contoh (individualisasi): Arifinto, politisi PKS, tertangkap tangan menonton video porno saat sidang paripurna DPR digelar. Contoh (asimilasi): Politisi tertangkap tangan menonton video porno saat sidang paripurna DPR digelar.

\section{Asosiasi-Disosiasi}

Strategi wacana asosiasi-disosiasi berhubungan dengan pertanyaan, apakah aktor atau suatu pihak ditampilkan sendiri ataukah dihubungkan dengan kelompok lain yang lebih besar. Misalnya, dapat dilihat dari contoh berikut: Disosiasi : Sebanyak 8 wisatawan Jepang menjadi sasaran jambret di wilayah Kintamani. Asosiasi : Orang Jepang di mana-mana 
menjadi sasaran penjambretan. Setelah di objek wisata Ubud, Sanur dan Kuta, sekarang di Kintamani. Sebanyak 8 orang mengalami musibah penjambretan.

\section{Hasil dan Pembahasan}

\section{Identitas Pelaku}

Meskipun Sankei dan Antaranews sama-sama media wacana berita online yang di dalamnya terdapat berita kriminal, tetapi tentu memiliki cara penyampaian informasi yang berbeda.

\section{(1) Individualisasi}

福岡県警小倉南署は 3 日、病院の職員駐車場で車に傷を付けたとして器物損壊の疑いで、北 九州市小倉南区下吉田の無職、坂本慎太郎容疑者（29）を逮捕した。

Fukuoka-kenkei Kokuraminami-sho wa mikka, byouin no shokuin chuushajou de kuruma ni kizu o tsuketa toshite kibutsu sonkai no utagai de, Kitakyuushuu-shi Kokuraminami-ku Shimoyoshida no mushoku, Sakamoto Shintarou yougisha (29) o taihoshita.

Terjemahan:

Kepolisian Prefektur Fukuoka, sektor Kokuraminami pada tanggal 3, menangkap seorang pengangguran bernama Sakamoto Shintarou (29 tahun) yang berdomisili di Shimoda, distrik Kokuraminami, ibukota Kitakyuushuu, dengan status sebagai tersangka atas tuduhan melakukan perusakan properti, dikarenakan merusak sebuah mobil di tempat parkir pegawai Rumah Sakit.

(Sankei.com, 03 Oktober 2019)

Pada kutipan berita kriminalitas tersebut menggunakan strategi wacana individualisasi, dikarenakan pada kalimat tersebut aktor ditampilkan secara spesifik. Aktor pelaku ditampilkan dengan menyebutkan identitas diri berupa nama pelaku, domisili, pekerjaan, dan umur. Identitas pelaku dapat diterangkan dengan jelas dikarenakan pelaku telah memiliki status kriminal yang ditetapkan kepolisian, ditandai dengan kosakata 容疑者/Yougisha yang artinya tersangka atau status dimana polisi memiliki keyakinan bahwa orang yang dimaksud merupakan pelakunya (Keijihiroba.com, 2016). Maka dalam kutipan berita tersebut pembaca dapat mengetahui individualisasi aktor atau pelaku.

\section{(2) Kategorisasi}

新聞専売所の出入りロドアをハンマーで割ったとして、兵庫県警丹波署は 4 日、器物損壊の 疑いで、兵庫県丹波篠山市に住む無職の男（５４）を現行犯逮捕した。

Shinbun senbaisho no deiriguchi doa o hanmaa de watta toshite, Hyougo-kenkei Tanba-sho wa yokka, kibutsu sonkai no utagai de. Hyougo-ken tanbasasayama-shi ni sumu mushoku no otoko (54) o genkouhan taihoshita.

Terjemahan:

Kepolisian Prefektur Hyogo, cabang stasiun Tanba pada tanggal 4, menangkap seorang pria pengangguran (54 tahun) yang berdomisili di ibukota Tamba Sasayama, Prefektur Hyogo, dikarenakan merusak pintu keluar masuk di gerai toko penjualan koran dengan menggunakan palu.

(Sankei.com, 05 Oktober 2019)

Pada kutipan berita kriminalitas tersebut menggunakan strategi wacana kategorisasi, dikarenakan pada kalimat tersebut tidak menerangkan identitas nama pelaku, melainkankan identitas pelaku diterangkan secara apa adanya, disertai dengan penyebutan kategori tertentu. Berbeda dengan kutipan koran dengan status pelaku yang sudah ditetapkan secara jelas oleh pihak kepolisian, pada kutipan berita ini masih belum ada kepastian status pelaku sehingga aktor pelaku ditampilkan secara apa adanya yaitu dengan menyebutkan jenis kelamin pelaku yakni seorang laki-laki yang disertai dengan kategori yaitu domisili dan pekerjaan. Kosakata yang digunakan untuk menerangkan jenis kelamin pada aktor pelaku 
yang merupakan laki-laki dewasa adalah otoko. Kosakata ini dipergunakan karena otoko memiliki tingkat kesopanan yang lebih rendah dibandingkan dansei (Nurhidayanti, 2016).

自宅のトイレ内に生後間もない乳児の遺体を遺棄したとして、宮城県警遠田署は 12 日、死 体遺棄の疑いで美里町の介護職員の女（20）＝犯行当時（19）＝を逮捕した。

Jitaku no toirenai ni seigo mamonai nyuuji no itai o ikishita toshite, Miyagi-kenkei Touda-sho wa juu ni-nichi, shitai iki no utagai de misato-chou no kaigo shokuin no onna (20) = hankou touji (19) = o taihoshita.

Terjemahan:

Kepolisian Prefektur Miyagi, sektor Touda pada tanggal 12, menangkap seorang perawat berjenis kelamin wanita (20 tahun) yang pada saat kejahatan (19 tahun) yang berdomisili di kota Misato, dengan tuduhan melakukan pembuangan mayat dikarenakan membuang orok bayi sesaat setelah lahir di kamar mandi yang berada di rumah.

(Sankei.com, 12 Oktober 2019)

Pada kutipan berita kriminalitas tersebut menggunakan strategi wacana kategorisasi, dikarenakan pada kalimat tersebut tidak menerangkan nama pelaku, melainkankan identitas pelaku diterangkan secara apa adanya, disertai dengan penyebutan kategori tertentu. Tindakan kriminal ini dilakukan oleh pelaku yang menurut UU Remaja Jepang pasal 2 dan 61 dapat dikategorikan sebagai pelaku yang masih dibawah umur pada saat melakukan tindakan kriminal, oleh sebab itu identitas nama pelaku tidak terangkan karena akan mempermudah pembaca untuk melacak informasi yang menyangkut identitas diri pelaku. Karena apabila identitas pelaku yang masih dibawah umur diketahui khalayak maka hal ini akan menghancurkan karir pelaku di masa depan dan nantinya ketika habis masa tahanan tidak dapat diterima kembali dimasyarakat. Kosakata yang digunakan untuk menerangkan jenis kelamin pada aktor pelaku yang merupakan wanita dewasa adalah onna. Kosakata ini dipergunakan karena onna memiliki tingkat kesopanan yang lebih rendah dibandingkan josei (Pawoko, 2013).

Antaranews sebagai media wacana berita Indonesia memiliki cara yang berbeda dalam memberikan informasi terkait identitas pelaku.

(3) Individualisasi

Tersangka atas nama Rizki Abadi (27) warga Cakung, Ronald Yohanes (21) warga Bekasi, dan Anggi Prasetyo (26) warga Cakung.

(Antaranews.com, 23 Oktober 2019)

Pada kutipan berita kriminalitas tersebut menggunakan strategi wacana individualisasi, dikarenakan pada kalimat tersebut aktor ditampilkan secara spesifik. Aktor pelaku ditampilkan dengan menyebutkan identitas diri berupa nama pelaku, domisili, pekerjaan, dan umur. Dengan menampilkan nama aktor pelaku dan kategorinya maka individu atau kelompok yang memiliki hubungan relasi dengan pelaku dapat segera mengenalinya. Disisi lain khalayak yang tidak memiliki relasi hubungan dengan pelaku akan mengetahui identitas diri pelaku dan warga daerahnya. Namun apabila terdapat kasus pemberitaan kriminalitas yang lain dimana asal aktor pelaku dari daerah yang sama maka hal ini akan menggeneralisasi bahwa warga wilayah tersebut identik dengan kriminalitas.

(4) Indeterminasi

Ina Yuniarti, terdakwa kasus video viral berisi ujaran kebencian terhadap Presiden Jokowi hari ini akan divonis di Pengadilan Negeri Jakarta Pusat.

(Antaranews.com, 14 Oktober 2019)

Pada kutipan berita kriminalitas tersebut menggunakan strategi wacana indeterminasi, karena pada kalimat tersebut aktor ditampilkan secara jelas. Identtas aktor pelaku ditampilkan dengan menyebutkan nama nya. Dengan menampilkan nama aktor pelaku, 
maka individu atau kelompok yang memiliki hubungan relasi dengan pelaku dapat segera mengenalinya. Penggunaan strategi wacana ini mempermudah pembaca untuk mengenali identitas pelaku yang dimaksud pada kasus video ujaran kebencian tersebut. Berbeda dengan penggunaan strategi wacana individualisasi, pada kutipan berita tersebut hanya menampilkan secara jelas aktor pelaku, tanpa menampilkan lebih dalam sosok identitas pelaku berupa kategorinya. Sehingga pembaca tidak mengenal lebih dalam aktor pelaku tersebut.

\section{(5) Kategorisasi}

Unit Reserse Kriminal Polsek Tambora menangkap pemuda pengangguran pelaku pencurian sepeda motor berinisial MA (21) di Krendang, Tambora, Jakarta Barat.

(Antaranews.com, 12 Oktober 2019)

Pada kutipan berita kriminalitas tersebut menggunakan strategi wacana kategorisasi, karena pada kalimat tersebut aktor pelaku ditampilkan apa adanya yaitu seorang pemuda dan kategorinya yaitu seorang pengangguran. Dengan penggunaan strategi wacana ini pembaca dapat mengetahui bahwa pelaku pencurian sepeda motor tersebut merupakan pemuda dari golongan pengangguran, tanpa mengetahui siapa sosok aktor sosial yang dimaksud.

(6) Nominasi

Tim Buru Sergap Polsek Tambora Jakarta Barat menciduk pemuda inisal AC (18), pelaku pemalakan terhadap supir truk di sekitar Jalan Pasar Buah Angke Tambora yang viral di media sosial.

(Antaranews.com, 19 Oktober 2019)

Pada kutipan berita kriminalitas tersebut menggunakan strategi wacana nominasi, dikarenakan pada kalimat tersebut tidak menerangkan nama pelaku, kategori tertentu melainkan hanya diterangkan secara apa adanya yaitu seorang pemuda yang berumur 18 tahun dengan inisial AC. Pemuda yang berumur 18 tahun sangat banyak, jadi pemuda yang disini tidak jelas menunjuk kepada siapa. Di dalam KBBI, kata pemuda sendiri memiliki makna seseorang yang berjenis kelamin laki-laki, berbeda dengan pemudi yang mengacu pada seseorang yang berjenis kelamin perempuan. Maka dengan penggunaan strategi wacana tersebut pembaaca hanya mengetahui bahwa pelaku pemalakan tersebut dilakukan oleh seorang yang berjenis kelamin laki-laki dengan umur 18 tahun.

\section{(7) Determinasi}

Anggota Polda Metro Jaya meringkus pelaku penculikan dan penganiayaan terhadap salah satu relawan Jokowi, Ninoy Karundeng berinisial RF dan S.

(Antaranews.com, 02 Oktober 2019)

Pada kutipan berita kriminalitas tersebut menggunakan strategi wacana determinasi, dikarenakan pada kalimat tersebut tidak menerangkan kejelasan identitas pelaku, melainkan aktor pelaku hanya ditampilkan dengan nama inisial yaitu RF dan S. Kata inisial di dalam Kamus besar bahasa Indonesia memiliki makna yaitu huruf pertama kata atau nama orang. Dengan adanya nama inisial tersebut tidak menjelaskan apapun mengenai identitas pelaku, selain menumbuhkan rasa penasaran pembaca untuk menduga sosok aktor pelaku dilihat dari nama inisial yang ditampilkan.

\section{Identitas Korban}

Setiap negara tentunya memiliki aturan atau cara tersendiri dalam menjelaskan korban dari suatu peristiwa. Begitu juga dengan berita Jepang pada koran Sankei dan berita Indonesia pada koran Antaranews. 
(1) Individualisasi

群馬県沼田市高橋場町の古書店で店員の斎藤康盛さん（５９）＝同市奈良町＝が殺害され、 現金などが奪われた強盗殺人事件で、同県警沼田署捜査本部は 29 日、強盗殺人などの疑い で、同県みなか夕町月夜野の会社員、高橋茂喜容疑者（2 8 ）を逮捕した。

Gunma-ken Numata-shi Takahashibamachi no kosho-ten de tenin no Saitou Yasumori-san (59) = doushi narachou = ga satsugaisare, genkin nado ga ubawareta goutou satsujin jiken de, dou kenkei Numata-sho sousa honbu wa ni juu ku-nichi, goutou satsujin nado no utagai de, douken Minakami-chou Tsukiyono no kaishain, Takahashi Shigeki yougisha (28) o taihoshita.

Terjemahan

Kepolisian Prefektur Gunma, sektor Numata divisi Investigasi pada tanggal 29, menangkap seorang karyawan bernama Takahashi Shigeki (28 tahun) dengan status sebagai tersangka yang berdomisili di Tsukiyono, kota Minakami, prefektur yang sama atas tuduhan melakukan perampokan dan pembunuhan dikarenakan telah melakukam pencurian uang dalam kasus perampokan sekaligus pembunuhan yang mengakibatkan terbunuhnya penjaga toko buku bekas di kota Takashiba, Ibukota Numata prefektur Gunma bernama Saitou Yasumori-san (59 tahun) yang tinggal di lbukota yang sama, di kota Nara.

(Sankei.com, 29 Oktober 2019)

Pada kutipan berita kriminalitas tersebut menggunakan strategi wacana individualisasi, dikarenakan pada kalimat tersebut aktor korban ditampilkan secara spesifik. Aktor korban ditampilkan dengan menyebutkan identitas diri berupa nama korban, domisili, pekerjaan, dan umur. Walaupun terdapat pemakaian strategi wacana yang sama antara aktor pelaku dan korban yaitu strategi wacana individualisasi, tetapi terdapat perbedaan dalam menampilkan identitas nama aktor, yakni nama aktor korban yang ditampilkan menggunakan kata sandang san.

Penggunaan kata sandang san dalam skala sosial memiliki makna menunjukan rasa hormat terhadap seseorang (Mangga, 2015). Dengan kata lain koran Sankei menunjukan bela sungkawanya sekaligus rasa hormat terhadap korban dari kasus perampokan sekaligus pembunuhan melalui digunakannya kata sandang san dalam menampilkan nama terhadap korban.

さいたま市見沼区の集合住宅で 9 月、小学 4 年の進藤遼佑君（9）が殺害された事件で、さ いたま地検は３１日、義父の無職、進藤悠介容疑者（３２）を殺人と死体遺棄の罪で起訴し た。

Saitama-shi Minuma-ku no shuugou juutaku de kugatsu, shougaku yonnen no Shindou Ryousuke-kun (9) ga satsugaisareta jiken de, Saitama-chiken wa san juu ichi-nichi, gifu no mushoku, Shindou Yuusuke yougisha (32) o satsujin to shitai iki no tsumi de kisoshita.

Terjemahan:

Pada kasus pembunuhan terhadap seorang anak kelas 4 SD bernama Shindou Ryousukekun (9 tahun) pada suatu komplek perumahan di ibukota Saitama pada bulan september, Kejaksaan wilayah Saitama pada tanggal 31, menvonis bersalah tersangka Shindou Yuusuke (28 tahun) seorang pengangguran yang merupakan ayah tiri korban atas dosa melakukan pembunuhan dan pembuangan mayat.

(Sankei.com, 31 Oktober 2019)

Pada aktor korban dalam kutipan berita ini, kata sandang yang dipergunakan adalah kata sandang kun yang umumnya digunakan pada pada seorang anak yang dianggap masih muda oleh penutur. Dalam skala sosial penggunaan kata sandang ini memiliki makna menunjukan hubungan kedekatan antara penutur dan mitra tutur (Mangga, 2015). Dari penggunaan strategi wacana individualisasi terhadap aktor pelaku dan korban dapat disimpulkan dalam menulis berita kriminal koran Sankei tidak memarginalkan korban dan juga menghormati korban dengan menggunakan kata sandang terhadap identitas nama aktor korban. Sebaliknya koran Sankei memiliki upaya untuk memarginalkan aktor pelaku dengan tidak menggunakan kata sandang dalam menampilkan identitas nama. 


\section{(2) Kategorisasi}

派遣型風俗店従業員の 20 代女性につきまとうなどのストーカー行為をしたとして、警視庁 町田署はストーカー規制法違反容疑で、九州工業大特任教授、金田寛容疑者（６８８）=北九 州市戸畑区仙水町二を逮捕した。

Haken-gata fuzokuten juugyouin no ni juu-dai josei ni tsukimatou nado no sutookaa koui o shita toshite, Keishi-chou Machida-sho wa sutookaa kiseihou ihan yougi de, Kyuushuu kougyoudai tokuninkyouju, Kaneda Hiroshi yougisha (68) = Kitakyuushuu Shitobata-ku Sensui-chou= o taihoshita.

Terjemahan:

Kepolisian metropolitan, sektor Machida menangkap seorang dosen di universitas institut teknologi Kyushu atas tuduhan melakukan pelanggaran terhadap hukum yang mengatur tentang penguntitan dikarenakan telah mengikuti dan membuntuti secara diam-diam terhadap seorang wanita yang berumur kisaran 20 tahun yang merupakan pegawai kontrak di rumah bordil.

(Sankei.com, 29 Oktober 2019)

Pada kutipan berita kriminalitas tersebut menggunakan strategi wacana kategorisasi, dikarenakan pada kalimat tersebut diterangkan secara apa adanya yaitu seorang wanita dengan kategori tertentu yaitu pekerja kotrak di rumah bordil. Tindakan kriminal yang dilakukan pelaku ini disebut sebagai tindak pelanggaran hukum yang mengatur penguntitan yang artinya keadaan korban hidup. Oleh sebab itu identitas nama korban tidak diterangkan karena akan merusak privasi yang dimiliki korban. Kehidupan sosial masyarakat di Jepang sangat menjunjung tinggi privasi seseorang (Tribunnews.com, 2018), yang artinya identitas seseorang tidak boleh di ungkap ke ranah publik kecuali dengan alasan yang tidak melanggar aturan tertentu. Kosakata yang digunakan untuk menerangkan jenis kelamin pada aktor korban yang merupakan wanita dewasa adalah onna. Kata ganti gender ini dipergunakan dikarenakan josei memiliki tingkat kesopanan yang lebih tinggi dan formal dibandingkan dengan kata ganti gender onna (Pawoko, 2013).

広島市佐伯区の老人ホームで入所男性（８３）を鉄パイプで殴ったとして、広島県警佐伯署 は 8 日、殺人未遂の疑いで、入所者の無職、三邑一美容疑者（７３） を逮捕した。

Hiroshima-shi Saeki-ku no roujin hoomu de nyuusho dansei (83) o tetsu paipu de nagutta toshite, Hiroshima-kenkei Saiki-sho wa youka, satsujin misui no utagai de, nyuushosha no mushoku, Mitsumura Kazumi yougisha (73) o taihoshita.

Terjemahan:

Kepolisian Prefektur Hiroshima, sektor Saiki pada tanggal 8, menangkap seorang pengangguran bernama Mitsumura Kazumi (73 tahun) yang merupakan pasien panti jompo di distrik Saeki, ibu kota Hiroshima atas tuduhan melakukan percobaan pembunuhan dikarenakan telah memukul seorang laki-laki (83 tahun) pasien panti jompo ditempat yang sama.

(Sankei.com, 08 Oktober 2019)

Pada kutipan berita kriminalitas tersebut menggunakan strategi wacana kategorisasi, dikarenakan pada kalimat tersebut tidak menerangkan nama pelaku, melainkankan yang diterangkan secara apa adanya yaitu seorang laki-laki dengan kategori tertentu. Pada kutipan berita tersebut masih belum ada kepastian bahwa korban telah meninggal dilihat dari tuduhan penanggkapan yang dipakai oleh kepolisian berupa satsujin misuil percobaan pembunuhan sehingga privasi identitas aktor korban harus dilindungi. Kosakata yang digunakan untuk menerangkan jenis kelamin pada aktor pelaku yang merupakan laki-laki dewasa adalah dansei. Kosakata ini dipergunakan karena dansei memiliki tingkat kesopanan yang lebih tinggi dibandingkan kata ganti gender otoko (Nurhidayanti, 2016).

(3) Nominasi 
埼玉県警朝霞署は 6 日、自宅で長女（４８） の首を絞めて殺したとして、殺人の疑いで朝霞 市栄町、無職、勝間田妙子容疑者（７2）を逮捕した。

Saitama-kenkei Asaka-sho wa rokka, jitaku de choujo (48) no kubi o shimete koroshita toshite, satsujin no utagai de Asaka-shi Sakae-chou, mushoku, Katsumata Taeko yougisha (72) o taihoshita.

Terjemahan:

Kepolisian prefektur Saitama, sektor Asaka pada tanggal 6 menangkap seorang pengangguran bernama Katsumata Taeko (72 tahun) dengan domisili di ibukota Asaka, kota Sakae atas tuduhan melakukan pembunuhan dikarenakan telah membunuh putri sulungnya (48 tahun) dirumahnya dengan dengan cara dicekik pada bagian leher.

(Sankei.com, 06 Oktober 2019)

Pada kutipan berita kriminalitas tersebut menggunakan strategi wacana nominasi, dikarenakan pada kalimat tersebut aktor ditampilkan apa adanya. Identitas aktor korban hanya disebutkan sebagai putri sulung/choujo. Pihak koran memiliki upaya untuk melindungi privasi korban dengan menutup rapat-rapat identitas aktor korban dengan menampilkan aktor korban tanpa disertai kategori atau indetifikasi tertentu. Pembaca hanya dapat mengetahui bahwa yang menjadi korban merupakan seorang putri sulung.

Antaranews sebagai media wacana berita Indonesia memiliki cara yang berbeda dalam memberikan informasi terkait identitas korban.

(4) Individualisasi

Polresta Manado telah melakukan penahanan terhadap FL (16), seorang siswa yang melakukan penganiayaan berupa penikaman terhadap Alexander Pangkey (54), guru SMK Ichtus Mapanget Manado pada Senin (21/10).

(Antaranews.com, 22 Oktober 2019)

Pada kutipan berita kriminalitas tersebut menggunakan strategi wacana individualisasi, karena di dalam berita tersebut identitas diri aktor korban disebutkan secara spesifik. Dengan menampilkan nama aktor korban dan kategorinya maka individu atau kelompok yang memiliki hubungan relasi dengan pelaku dapat segera mengenalinya. Disisi lain khalayak yang tidak memiliki relasi hubungan dengan korban akan mengetahui identitas diri korban dan yang menjadi korban merupakan seorang guru.

\section{(5) Kategorisasi}

Siswa Sekolah Menengah Kejuruan (SMK) berinisial R (17) menjadi korban pembacokan saat terjadi tawuran pelajar di kawasan Jalan Kyai Tapa, Grogol Petamburan, Jakarta Barat, Selasa sore.

(Antaranews.com, 15 Oktober 2019)

Pada kutipan berita kriminalitas tersebut menggunakan strategi wacana kategorisasi, karena pada kalimat tersebut aktor ditampilkan apa adanya yaitu seorang siswa dan kategorinya yaitu pendidikan SMK. Dengan penggunaan strategi wacana ini pembaca dapat mengetahui bahwa yang menjadi korban dari tindakan pembacokan tersebut merupakan seorang laki-laki yang berasal dari golongan pelajar, yakni siswa dari Sekolah Menengah Kejuruan tanpa mengetahui secara jelas siapa sesungguhnya individu yang dimaksud.

(6) Nominasi

Seorang pria paruh baya berinisial JD (52) kini harus berurusan dengan aparat penegak hukum lantaran menipu seorang perempuan yang dikenalnya lewat media sosial.

(Antaranews.com, 28 Oktober 2019)

Pada kutipan berita kriminalitas tersebut menggunakan strategi wacana nominasi, Jurnal Pendidikan Bahasa Jepang | 70 
dikarenakan pada kalimat tersebut tidak menerangkan nama korban, melainkan diterangkan secara apa adanya yaitu seorang perempuan. Kata perempuan menunjuk pada jenis kelamin, yang berarti bersifat umum. Maka dengan penggunaan strategi wacana tersebut pembaca hanya mengetahui bahwa korban penipuan tersebut seseorang perempuan.

(6) Determinasi

Pemerasan tersebut disertai dengan perampasan kemerdekaan seseorang dan pengeroyokan yang dilakukan oleh tiga tersangka berinisial RA (48), BM (46), dan AL (24) terhadap korban berinisial JL (37).

(Antaranews.com, 08 Oktober 2019)

Pada kutipan berita kriminalitas tersebut menggunakan strategi wacana determinasi, dikarenakan pada kalimat tersebut tidak menerangkan nama korban, melainkan aktor korban hanya ditampilkan dengan nama inisial yaitu JL dengan umur 37 tahun. Penggunaan nama inisial pada kutipan berita tersebut tidak menjelaskan apapun mengenai identitas korban selain inisial dan umur yang tidak memberikan informasi apapun terhadap identitas korban. Pembaca tidak mengetahui kejelasan mengenai aktor korban, melainkan yang dapat diketahui hanya aktor korban yang berumur 37 tahun.

Dalam menampilkan aktor korban, koran Antaranews sebagian besar menggunakan strategi wacana individualisasi, yang mana identitas aktor nama pelaku yang ditampilkan disebutkan dengan jelas beserta kategorinya.. Hal ini dikarenakan koran Antaranews memiliki upaya untuk menarik minat pembaca dengan menampilkan identitas korban secara spesifik. Dalam hal ini dapat dikatakan koran Sankei melakukan tindakan permarginalan terhadap korban.

\section{Simpulan dan Saran}

Berdasarkan hasil penelitian dan pembahasan mengenai pengungkapan identitas pelaku maupun korban yang ditampilkan lewat pemberitaan pada koran Sankei dan Antaranews dapat disimpulkan sebagai berikut.

(1) Koran Sankei melakukan pemarginalan terhadap aktor pelaku, dengan tidak digunakannya kata sandang dalam menyebutkan identitas nama, pemakaian diksi untuk menyebut jenis kelamin yang memiliki tingkat kesopanan lebih rendah dan sebagian besar berita yang menampilkan identitas aktor pelaku secara spesifik.

(2) Koran Antaranews melakukan pemarginalan terhadap aktor korban, dengan sebagian besar berita yang menampilkan identitas aktor korban secara spesifik, berbeda dengan aktor pelaku yang sebagian besar ditutupi identitasnya dengan penggunaan inisial nama.

Berdasarkan hasil penelitian dari simpulan, maka peneliti dapat menyarankan hal-hal sebagai berikut.

(1) Untuk peneliti yang berminat mengkaji lebih dalam mengenai analisis wacana kritis yang dikembangkan Theo Van Leeuwen bisa digunakan pada aktor sosial yang ditampilkan pada sumber selain koran seperti, majalah, novel, buku, dakwah, dll.

(2) Untuk peneliti lainnya bisa membandingkan aktor sosial yang ditampilkan lewat pemberitaan pada beberapa koran Jepang agar dapat menambah pengetahuan.

\section{Daftar Pustaka}

Antaranews. 08 Oktober 2019. Kasus pemerasan 'polisi gadungan' di Tanah Abang terungkap. Tersedia pada https://www.antaranews.com/berita/1102574/kasuspemerasan-polisi-gadungan-di-tanah-abang-terungkap (Diakses pada 09 Oktober 2019)

Antaranews. 23 Oktober 2019. Pelaku pemalakan sopir truk di Cakung ditangkap sejam setelah viral. Tersedia pada https://www.antaranews.com/berita/1126840/pelaku- 
pemalakan-sopir-truk-di-cakung-ditangkap-sejam-setelah-viral (Diakses pada 24 Oktober 2019)

Antaranews. 14 Oktober 2019. Wanita yang viralkan video kebencian terhadap Jokowl divonis hari ini. Tersedia pada https://www.antaranews.com/berita/1111138/wanita-yangviralkan-video-kebencian-terhadap-jokowi-divonis-hari-ini (Diakses pada 15 Oktober 2019)

Antaranews. 15 Oktober 2019. Tawuran pelajar di Grogol, korban dibacok dari belakang. Tersedia pada https://www.antaranews.com/berita/1114524/tawuran-pelajar-di-grogolkorban-dibacok-dari-belakang (Diakses pada 16 Oktober 2019)

Darma, Yoce Aliah. 2014. Analisis Wacana Kritis dalam Multiperspektif. Bandung: Refika Aditama

Efendi, Ilham. 2016. 7 Situs Berita Online Terpopuler di Indonesia. Tersedia pada https://www.it-jurnal.com/situs-berita-terpopuler-di-indonesia (Diakses pada 14 Oktober 2019)

Eriyanto.2001. Analisis Wacana: Pengantar Analisis Teks. Yogyakarta: LKiS Pelangi Aksara

Nagai, Minami. 2017. The Leading Japanese Newspapers - Printed, Online, and with English Translations. Tersedia pada http://yabai.com/p/3464 (Diakses pada 13 Oktober 2019)

Nurhidayanti, Dwiyan Eva. 2016. Penggunaan Kata Otoko dan Dansei dalam Bahasa Jepang. Malang: Universitas Brawijaya. Tersedia pada http://repository.ub.ac.id/id/eprint/102230 (Diakses pada 06 Nopember 2019).

Pawoko, Himawan Giri. 2013. Analisis perbandingan makna kata Onna dan Josei. Yogyakarta: Universitas Gadjah Mada. Tersedia pada http://etd.repository.ugm.ac.id/index.php?mod=penelitian detail\&sub=PenelitianDetail\&a ct=view\&typ=html\&buku id=65489 (Diakses pada 07 Nopember 2019).

Rakhmat, Jalaluddin. 2001. Metode Penelitian Komunikasi. Bandung: Remaja Rosdakarya.

Sankei. 05 Oktober 2019. Shinbun senbai-sho no doa hakai utagai de otoko taiho Hyougo tanba. Tersedia pada https://www.sankei.com/affairs/news/191005/afr1910050003$\underline{\mathrm{n} 1 . \mathrm{html}}$ (Diakses pada 06 Oktober 2019)

Sankei. 06 Oktober 2019. Yon juu hachi-sai musume satsugai utagai, haha taiho Saitama Asagasumi. Tersedia pada https://www.sankei.com/affairs/news/191006/afr1910060013-n1.html (Diakses pada 07 Oktober 2019)

Sankei. 08 Oktober 2019. Roujin hoomu nyuushosha o tetsu paipu de naguru satsujin misui yougi de otoko taiho. Tersedia pada https://www.sankei.com/region/news/191008/rgn1910080034-n1.html (Diakses pada 09 Oktober 2019)

Sankei. 12 Oktober 2019. Toirenai ni nyuuji no itai wo iki ni juu-sai no onna wo taiho Miyagi kenkei Touda-sho. Tersedia pada https://www.sankei.com/affairs/news/191012/afr1910120004-n1.html (Diakses pada 13 Oktober 2019) 